\title{
EDIBLE MUSHROOM Pleurotus sajor-caju PRODUCTION ON WASHED AND SUPPLEMENTED SUGARCANE BAGASSE
}

\author{
Evelise Moncaio Moda; ${ }^{1}$ Jorge Horii; ${ }^{2 *}$ Marta Helena Fillet Spoto² \\ ${ }^{1}$ USP/ESALQ - Programa de Pós-Graduação em Ciência e Tecnologia de Alimentos. \\ ${ }^{2}$ USP/ESALQ - Depto. de Agroindústria, Alimentos e Nutrição, C.P. 09 - 13418-900 - Piracicaba, SP - Brasil. \\ *Corresponding author<jhorii@esalq.usp.br>
}

\begin{abstract}
Traditionally, the cultivation of Pleurotus sajor-caju is performed on different composted and pasteurized agricultural residues. The objective of this study was to investigate whether traditional composting and pasteurization processes could be replaced by washed and supplemented (mineral or organic) sugarcane bagasse. In one experiment, fresh sugarcane bagasse was immersed in hot water at $80^{\circ} \mathrm{C}$ for two hours (control) or washed in fresh water for one hour using an adapted machine for residue treatment. In another experiment, fresh sugarcane bagasse was washed in fresh water (control), and supplemented with corn grits (organic supplementation), or supplemented with nutrient solution (mineral supplementation). In the first experiment, the washed bagasse presented a average biological efficiency (ABE) of $19.16 \%$ with $44 \%$ contamination, and the pasteurized bagasse presented a ABE of $13.86 \%$ with $70 \%$ contamination. In the second experiment, corn grits presented the poorest performance, with a $\mathrm{ABE}$ of $15.66 \%$ and $60 \%$ contamination, while supplementation with the nutrient solution presented a ABE of $30.03 \%$, whereas the control of $26.62 \%$. Washing fresh sugarcane bagasse could suppress the pasteurized substrate in Pleurotus sajor-caju production, compensating a reduced $\mathrm{ABE}$ with a faster process.
\end{abstract}

Key words: basidiomycetes, substrate, pasteurization, supplementation

\section{PRODUÇÃO DO COGUMELO COMESTÍVEL Pleurotus sajor-caju EM BAGAÇO DE CANA-DE-AÇÚCAR LAVADO E SUPLEMENTADO}

\begin{abstract}
RESUMO: Tradicionalmente, o cultivo do Pleurotus sajor-caju é realizado utilizando-se diversos resíduos agrícolas, precedido dos processos de compostagem e pasteurização. O presente trabalho teve por objetivo comparar o processo de pasteurização com a lavagem do bagaço de cana-de-açúcar e avaliar formas de suplementação do bagaço, visando aumento na produtividade. No primeiro experimento, os colmos da canade-açúcar passaram por moenda para a extração do caldo, sendo em seguida desfibrados. No tratamento controle, o bagaço fresco foi pasteurizado em água a $80^{\circ} \mathrm{C}$ durante 2 horas e o outro tratamento consistiu na lavagem do bagaço fresco em centrífuga com água corrente à temperatura ambiente, por uma hora. No segundo experimento, utilizou-se a lavagem simples (tratamento controle), a suplementação do bagaço lavado com quirera de milho (suplementação orgânica) e com solução mineral (suplementação mineral). A eficiência biológica média (EBM) do cogumelo no bagaço fresco lavado $(19,16 \%)$ não diferiu significativamente da obtida no bagaço fresco pasteurizado (13,86\%), sendo a sua contaminação (44\%) menor do que no bagaço pasteurizado (70\%). No segundo experimento, a suplementação orgânica obteve o menor desempenho, com EBM de 15,66\% e contaminação de $60 \%$, diferindo da suplementação mineral e controle, com EBM de 30,03\% e 26,62\%, respectivamente. A lavagem do bagaço de cana-de-açúcar fresco poderá suprimir a pasteurização do substrato na produção de Pleurotus sajor-caju, compensando a eficiência biológica reduzida com a agilidade do processo.

Palavras-chave: basidiomycetes, substrato, pasteurização, suplementação
\end{abstract}

\section{INTRODUCTION}

Several agricultural residues have been used to produce the edible mushroom Pleurotus sp., also known as "oyster mushroom", "hiratake", "shimeji", or "houbitake” (Mizuno \& Zhuang, 1995; Bononi et al., 1995). Among these residues, the use of sugarcane bagasse allows a byproduct to be utilized in the production of a food of high nutritional value, with a protein content of up to $40 \%$ in dry matter (Rajarathnam \& Bano,
1989). The abundant supply of this agricultural surplus turns Brazil into a country with a great mushroom-producing potential, because using $25 \%$ to $30 \%$ of the bagasse produced by Brazilian sugar/alcohol mills (25 million tons) world's mushroom supply could be doubled (Ferreira, 1998).

Among the substrates used to produce Pleurotus sp., are worth mentioning: rice hulls mixed with cotton residues for the production of Pleurotus sajor-caju (Fr.) Singer (Chang et al., 1981), banana leaf, mixed with sug- 
arcane bagasse or corn cob for the production of Pleurotus sp. (Sturion \& Oetterer, 1995a), and also cassava residues with sugarcane bagasse for the production of Pleurotus ostreatus (Jacquim Fries) Kummer (Felinto, 1999).

Substrate supplementation is a practice that has been used to produce Pleurotus sp. in order to increase productivity, evaluated through biological efficiency in several reports (Chang, 1980; Madan et al., 1987; Sturion \& Oetterer, 1995a; Dhanda et al., 1996). Among various tested supplements, mulberry leaves and stalks were used in rice hull supplementation for the production of Pleurotus sajor-caju (Madan et al., 1987), while wheat bran and calcium carbonate were used in sugarcane bagasse supplementation for the production of Pleurotus sp. (Maziero et al., 1992).

The methodology for substrate preparation described in several studies consists in composting agricultural residues, followed by pasteurization, which can be carried out in different ways. The most common process is the use of vapor injected into chambers or tunnels, where the substrate is packaged and pasteurization time varies as a function of the temperature (Zadrazil, 1980; Abe et al., 1992; Mansur et al., 1992, and Maziero et al., 1992). Other forms of pasteurization include immersion of the substrate in hot water (Stamets, 1993; Balasubramanya \& Kathe, 1996), and substrate sterilization in autoclaves (Zanetti \& Ranal, 1996).

The main difficulty for Pleurotus sp. cultivation is the substrate disinfestation stage, performed by pasteurization or sterilization (Wizentier et al., 1996). Therefore, the introduction of a new methodology to produce substrate that would exclude the pasteurization stage becomes interesting, since it would allow mushrooms to be grown by a larger number of producers, with reductions in costs and production time, facilitating management.

The objective of the present work was to evaluate production and quality of the edible mushroom Pleurotus sajor-caju cultivated on fresh and washed sugarcane bagasse, supplemented with a nutrient solution or with corn grits.

\section{MATERIAL AND METHODS}

Production of inoculum: the production of inoculum in Petri dishes and its conservation in test tubes was performed according to Bononi et al. (1995).

Production of spawn: corn grain was cooked for 15 minutes, drained and cooled, and $0.5 \%$ calcium carbonate were added in relation to their mass (Gabrielli et al., 2002), then transferred into $25 \times 35 \mathrm{~cm}$ clear polypropylene bags, with a mean thickness of $0.6 \mathrm{~mm}$, containing a $1.5 \mathrm{~cm}$ diameter hole as an air passage on its upper portion ( $2 \mathrm{~cm}$ below the edge), sealed with Micropore ${ }^{\circledR}$ tape
( $2 \mathrm{~cm}$ length $\times 1 \mathrm{~cm}$ width). The bags were sterilized, inoculated, and incubated according to Bononi et al (1995).

Production on washed substrate: sugarcane bagasse from the variety RB76-5418, was prepared according to the following scheme:

stalk cutting and cleaning $\Rightarrow$ fiber removal $\Rightarrow$ passage through a mill $\Rightarrow$ juice extraction $\Rightarrow$ fresh bagasse

Fresh bagasse was used as the control treatment, packaged in cotton bags and submitted to pasteurization in water at $80^{\circ} \mathrm{C}$ for 2 hours in a 1,000 liter capacity container (Bahukhandi \& Munjal, 1989; Balasubramanya \& Kathe, 1996). The bagasse was then cooled down and drained in a hydraulic press until a mean moisture of $60 \%$ calculated by drying $100 \mathrm{~g}$ wet bagasse in an oven at $70^{\circ} \mathrm{C}$ until constant weight, with three replicates per sample. The pasteurized substrate was manually packaged into 30 $\times 40 \mathrm{~cm}$ clear polyethylene bags of mean thickness 0.15 $\mathrm{mm}$, with $665 \mathrm{~g}$ wet bagasse per bag, together with $35 \mathrm{~g}$ spawn (5\% in relation to the wet mass of the substrate).

The other treatment consisted of fresh bagasse washed in running water at room temperature for one hour, in a device used for washing cassava billets. This device consists of a cylindrical sieve that makes rotary movements, performed by means of a smooth belt, with a water inlet that allows the material to be washed inside the cylinder. After washing, the bagasse was drained and packaged as described for the control treatment. Both treatments were taken to a growing-room constructed in brickwork and clay roofing tiles, and then laid on wooden shelves $70 \mathrm{~cm}$ above ground. An $80 \%$ shade cloth was used to seal the window and door, in order to reduce moisture loss from the environment and avoid the access of insects that could be harmful during cultivation. Temperature in the environment ranged from $20-25^{\circ} \mathrm{C}$, and relative humidity $70-90 \%$. The temperature and humidity in the environment were adjusted by a microprocessor-based thermohygrometer, and aeration was controlled by means of an exhaust fan that was turned on 1 hour/ day during the mushroom production stage. Mushrooms were collected during three flushes over a 50-day period.

Production on supplemented substrate: the chamber and shelves used in the previous experiment were washed with water and neutral dishwashing detergent. The environment was next sprayed with a Bordeaux mixture (10 liters water mixed with $100 \mathrm{~g}$ quicklime and $100 \mathrm{~g}$ copper sulfate) to disinfect the site. The growing-room was left to rest for a 2-day period after spraying.

The same washing procedure previously described was used to obtain the bagasse, which was divided into three portions. In for control the washed bagasse was manually packaged into $30 \times 40 \mathrm{~cm}$ clear polyethylene bags (mean thickness $0.15 \mathrm{~mm}$ ), with $465 \mathrm{~g}$ wet bagasse 
per bag (mean humidity of 60\%), together with $24 \mathrm{~g}$ spawn (5\% in relation to the wet mass of the substrate). The second treatment received organic supplementation, adding manually $45 \mathrm{~g}$ of corn grits (cooked for 15 minutes) to 420 g wet bagasse and 24 g spawn when the substrate was packaged into the polyethylene bags. The third treatment was prepared as described for the control, and received mineral supplementation after 10 days of incubation in the growing-room by addition of $20 \mathrm{~mL}$ nutrient solution to each plot, injected through the upper part of the bags when they were partially colonized by mycelium. The nutrient solution was adapted from hydroponic curly lettuce cultivation (IAC, 1996), with the following composition in $200 \mathrm{~mL}$ distilled water: 7.5 g calcium nitrate; $5.0 \mathrm{~g}$ potassium nitrate; $1.5 \mathrm{~g}$ monoammonium phosphate; $4.0 \mathrm{~g}$ magnesium sulfate; $0.25 \mathrm{~mL}$ EDTA iron; and $1.0 \mathrm{~mL}$ micronutrients solution (5.0 g manganese sulfate; $0.5 \mathrm{~g}$ zinc sulfate; $1.0 \mathrm{~g}$ boric acid; 0.2 g copper sulfate; and 0.2 g sodium molybdate in one liter of distilled water).

The treatments thus prepared were taken to the growing-room, where they remained during the incubation and harvest periods, under the same conditions of the first experiment.

\section{Experimental design}

Production on washed substrate - samples were distributed completely at random, with two treatments (washed and pasteurized) and 10 replicates. The test used to compare means was a nonparametric rank-sum test (Wilcoxon test) at 5\%. The software used for the statistical analysis was the Statistical Analyses System (SAS Institute, 2000).

\section{Production on supplemented substrate -} samples were distributed completely at random, with three treatments (control, organic supplementation, and mineral supplementation) and 10 replicates. The Tukey test was used at 5\% (SAS Institute, 2000).

\section{Characteristics evaluated}

- Contamination: quantification of samples that stopped producing due to contaminations that occurred during the experiment, expressed as percentage.

- Average biological efficiency (ABE), obtained by the average biological efficiencies of the plots of each treatment, using the expression:

$\mathrm{ABE} \%=$ total wet mass of mushrooms/dry mass of the initial substrate x 100 (Chang et al., 1981; Maziero et al., 1992). The total wet mass of mushrooms was obtained by the sum of yields recorded during three flushes; dry mass of the initial substrate was calculated by subtracting the mean moisture in the bagasse (60\%) from its wet mass in each treatment.
- Brix degree determination in natural, pasteurized, and washed sugarcane bagasse, based on the average of three subsamples.

- Analysis of macro- and microelements present in washed sugarcane bagasse and in the mushroom Pleurotus sajor-caju produced on washed substrate without supplementation, based on the average of three subsamples.

\section{RESULTS AND DISCUSSION}

\section{Production on washed substrate:}

The spawn run on the substrate could be observed from the third day of incubation in the growing-room, with the formation of light pink halos around the spawn, indicating the beginning of degradation of the substrate by the fungus. The natural induction of primordia on the washed and pasteurized substrates occurred between 1517 days of incubation, and the first flush or harvest occurred after 20 days of incubation. The mushrooms sprouted in clusters, and had the grayish-brown color that is characteristic for the species (Stamets, 1993). The second and third flushes occurred 15 and 30 days after the first yield, respectively, and lasted 7-8 days. This behavior was similar in all plots, except in those that stopped producing due to contamination of the substrate by competing microorganisms. Therefore, one harvest was obtained every 15 days, totaling a period of 50 days between the beginning of mycelium formation and the third flush, after which the substrates were discarded.

The Shapiro-Wilk test was used to test the normality hypothesis, required to compare average biological efficiencies; the statistic $\mathrm{W}=0.8217(P=0.002404)$ revealed that the residues lacked normality, considering a 5\% significance level. Therefore, the Wilcoxon test was used to make the comparisons, with a statistic value of $\mathrm{W}=24$. Considering the corresponding value of $P=$ 0.09472 and a 5\% significance level, the hypothesis that the average biological efficiencies were equal was not rejected, indicating that the treatments were not different (Table 1).

Table 1 - Average biological efficiency (ABE) of washed and pasteurized substrates in Pleurotus sajor-caju cultivation.

\begin{tabular}{lc}
\hline Treatment & \multicolumn{1}{c}{ ABE } \\
\hline & $--\cdot-16 \pm 7.97 \mathrm{a}$ \\
Washed & 19.16 \\
CV $(\%)$ & $13.86 \pm 8.47$ a \\
Pasteurized & 61.1 \\
\hline CV $(\%)$ & \\
\hline
\end{tabular}

Means followed by the same letter are not different by Wilcoxon test at $5 \%$.

$\mathrm{CV}$ : coefficient of variation. 
Different types of substrates have been used to grow Pleurotus sajor-caju in several papers, with ABE values from $32.10 \%$ to $79.18 \%$ (Chang et al., 1981; Bahukhandi \& Munjal, 1989; Colauto \& Eira, 1995; Sturion \& Oetterer, 1995a; Dhanda et al., 1996). The low average biological efficiency in the washed and pasteurized treatments, as well as the biological efficiency variation, as indicated by the coefficient of variation and the standard deviation of the mean (Table 1), could be partially attributed to the loss of samples resulting from contaminations that occurred during the $2^{\text {nd }}$ and $3^{\text {rd }}$ flushes. The intrinsic variability of the biological material, its phenotypic plasticity, and the type of substrate used could also have influenced the results.

Contaminations may occur in most cultivations, because the mycelium becomes weaker after successive cultivations, or due to inappropriate management (Ferreira, 1998). Here contamination of the pasteurized substrate occurred in almost all samples (70\%), usually after the $1^{\text {st }}$ flush; in the washed substrate, the contamination percentage was $44.44 \%$, appearing during the $3^{\text {rd }}$ flush. Wizentier et al. (1996), working with the same species grown on sugarcane bagasse after juice extraction at $58^{\circ} \mathrm{C}$ (mill bagasse), bagasse stored for 30 days, and sterilized mill bagasse, recorded substrate contaminations of $30 \%, 10 \%$, and $10 \%$, respectively, with different microbiotas with regard to type and amount, and similar mycelium production velocities in all treatments. In spite of the greater contamination in mill bagasse, the authors suggested that this substrate is viable to be used in the production of Pleurotus sajor-caju, without pasteurization or sterilization of the substrate.

According to Balasubramanya \& Kathe (1996), the microorganism species that competed with Pleurotus sp. after pasteurization with hot water $\left(80^{\circ} \mathrm{C}\right.$ for 2 hours) were the fungi Penicillium sp. and Trichoderma sp., probably due to the partial breakdown of cellulose and hemicellulose, making them available to competitors. Pasteurization at $90^{\circ} \mathrm{C}$ could make cellulose more available (Sturion \& Oetterer, 1995a), due to the partial destruction of the lignin-cellulose bonds, favoring substrate contamination. Thus, contamination of the pasteurized substrate could have occurred because of the temperature and time used during pasteurization, since the literature is quite variable with reference to these characteristics (Bahukhandi \& Munjal, 1989; Stamets, 1993;
Balasubramanya \& Kathe, 1996; and Sturion \& Ranzani, 1997).

In the traditional cultivation of edible mushrooms, composting has the function of digesting simple sugars by the action of microorganisms present in the residues that make up the substrate, in addition to making some nutrients available in the biomass, and making it more homogeneous (Rajarathnam \& Bano, 1989). The competing microorganisms present in the compost are partially eliminated during the pasteurization process, or totally eliminated by the sterilization process (Bononi et al., 1995). The compost thus obtained is selective, reducing the potential for contamination during cultivation, but generating higher costs in labor and facilities, and demanding more time with respect to bagasse washing.

The mean soluble solid content values were $16.5^{\circ}$ Brix for the fresh sugarcane bagasse used in the experiments, $1.8^{\circ}$ Brix for the pasteurized bagasse, and $0.3^{\circ}$ Brix for the washed bagasse. The low amount of soluble solids, especially simple sugars, caused by washing the freshly-obtained bagasse, is important to reduce surface contamination, since the conventional pasteurization process has been suppressed. Therefore, sugarcane bagasse washing can be used for Pleurotus sajorcaju cultivation, as long as the bagasse has been recently obtained and used, avoiding the natural fermentation of the stacked material. When the percentage of losses resulting from contaminations and the cost of the disinfestation process for the cultivation substrate are compared, the results here presented indicate that the washing technique is promising for the production of this mushroom.

The chemical composition of the mushroom and of the substrate used for growing shows that Pleurotus sajor-caju is effective in concentrating $\mathrm{N}, \mathrm{K}, \mathrm{P}, \mathrm{Mg}, \mathrm{S}$, $\mathrm{Na}, \mathrm{Fe}, \mathrm{Zn}$, and $\mathrm{Cu}$ in their fruit bodies (Table 2). This makes mushrooms of this genus to be good sources of minerals, in addition to having low calorie contents, with little digestible carbohydrates and a small amount of lipids (Sturion \& Ranzani, 1997).

The most abundant mineral in mushrooms is potassium, comprising between $56 \%$ and $70 \%$ of the total ash in the organic matter, followed by phosphorus, sodium, calcium, and magnesium (Chang \& Miles, 1984). For comparative purposes, the amounts of minerals in

Table 2 - Mean macro- and microelement composition of washed sugarcane bagasse and of the mushroom Pleurotus sajorcaju collected from washed substrate without supplementation.

\begin{tabular}{lccccccccccccc}
\hline Sample & $\mathrm{N}$ & $\mathrm{K}$ & $\mathrm{P}$ & $\mathrm{Mg}$ & $\mathrm{S}$ & $\mathrm{Ca}$ & $\mathrm{Al}$ & $\mathrm{Na}$ & $\mathrm{Fe}$ & $\mathrm{Zn}$ & $\mathrm{Cu}$ & $\mathrm{Mn}$ & $\mathrm{B}$ \\
\hline Bagasse & $0.48^{*}$ & $0.12 *$ & 225 & 425 & 294 & 654 & 39 & 50 & 96 & 23 & 2.4 & 20 & 2.9 \\
Mushroom & $17.4 *$ & $4.32 *$ & $1.97 *$ & $0.46^{*}$ & $0.77 *$ & 102 & 42 & 215 & 163 & 192 & 14 & 21 & 3.0 \\
\hline
\end{tabular}

*Expressed as \% in dry matter (D.M.).

Other elements expressed as $\mu \mathrm{g} \mathrm{g}^{-1}$ in D.M. 
Pleurotus sp. recorded by several authors were transformed to \% (K, P, and $\mathrm{Mg}$ ) and $\mathrm{mg} \mathrm{g}^{-1}$ (Na, Ca, Fe, Zn, $\mathrm{Cu}$, and $\mathrm{Mn}$ ) in dry matter (D.M.). Thus, K (2), P (0.75), and $\mathrm{Mg}(0.15)$ were the major constituents in Pleurotus species, while $\mathrm{Ca}$ and Fe were present at low concentrations in the D.M., with 1,200 and $500 \mathrm{mg} \mathrm{g}^{-1}$, respectively, according to Bano \& Rajarathnam (1988). In a review made by Buswell \& Chang (1993), the following values were found: $\mathrm{K}$ (3.3 to 5.3), P (0.76 to 1.08), Na (1,650 to 1,840$)$, Ca (200 to 240$)$, and Fe (60 to 2,240) for Pleurotus sajor-caju grown on several substrates, while Justo et al. (1998) obtained values of 0.5 to 0.95 for $\mathrm{P}$ and 7,900 to 18,500 for Ca in three Pleurotus ostreatus strains grown on wheat straw. In the cultivation of Pleurotus sajor-caju on banana leaf and sugarcane bagasse, however, Sturion \& Oetterer (1995b) found the following mean values: $\mathrm{K}(0.99), \mathrm{P}(0.70), \mathrm{Mg}(0.13)$, Ca (400), Fe (175), Zn (35), Cu (12), and Mn (12). Thus, from the values in Table 2 and those found in the literature, a variation can be seen in the analyzed minerals; the inferring that the type of substrate and the species used in the cultivation have an influence on the fungal chemical composition.

The concentration of elements in the mushroom (Table 2) can be better observed because it is collected from washed sugarcane bagasse, where no interference of supplementation was found. Thus, the concentration of $\mathrm{N}$ and minerals in the mushroom occurs because of the fungus metabolism, which could be correlated with other mechanisms, such as nitrogen fixation by Pleurotus sp. (Ortega et al., 1992; Sturion \& Oetterer, 1995a; and Patrabansh \& Madan, 1997) and the occurrence of microorganisms associated with mushrooms of this genus, similar to the bacterium Burkholderia, which could also be related with nitrogen fixation in this system (Yara, 2002).

Production on supplemented substrate: after installation of the experiment, the induction of primordia occurred in all treatments, between 14-17 days of incuba-

Table 3 - Average biological efficiency (ABE) of substrates: washed, washed with organic supplementation, and washed with mineral supplementation, in Pleurotus sajor-caju cultivation.

\begin{tabular}{lc}
\hline Treatment & ABE \\
\hline Washed with mineral supplementation & $-----\%----$ \\
Washed (control) & $30.03 \pm 2.39 \mathrm{a}$ \\
Washed with organic supplementation & $15.66 \pm 3.40 \mathrm{~b}$ \\
CV (\%) & 15.46
\end{tabular}

Means followed by the same letter are not different by Tukey test at $5 \%$.

$\mathrm{CV}$ : coefficient of variation. tion, with three flushes. The first occurred after three days from primordium formation, with a 7-day interval between flushes; one harvest was obtained every 15 days, totaling a 50-day period between the onset of mycelium formation on the substrates and the last harvest.

The Shapiro-Wilk test was run in order to verify the normality assumption, required to perform analysis of variance, with a $\mathrm{W}$ value of $0.9824(\mathrm{p}=0.8854)$; therefore, the normality hypothesis was not rejected. Organic supplementation obtained the smallest $A B E$ value (15.66\%), being statistically different from the control (26.63\%) and from mineral supplementation (30.03\%), according to Table 3 . This result may have occurred due to the contamination caused by the manual introduction of cooked corn grits, so that organic supplementation did not respond satisfactorily to this production methodology. Contamination for the washed substrate with organic supplementation was $60 \%$, hurting productivity and interrupting production after the $2^{\text {nd }}$ flush. However, in traditional mushroom production, organic supplementation with nitrogen-rich residues, such as soybean bran, is frequently used, and according to Permana et al. (2000), it provides superior results when compared with supplementation based on inorganic nitrogen sources, such as ammonium nitrate and calcium nitrate.

Zanetti \& Ranal (1997) used pigeon pea at different percentages as a supplement to sugarcane bagasse in the production of Pleurotus sp. "Florida", and the best result was obtained with the incorporation of $15 \%$ pigeon pea, with an ABE of 94.73\%. Zadrazil (1980) used wheat straw supplementation with soybean bran and alfalfa, increasing the productivity of Pleurotus sajor-caju by $300 \%$; the author also used supplementation with ammonium nitrate, increasing productivity by $50 \%$. According to these authors, the addition of nitrogen to an alkaline substrate stimulates the formation of mycelium and the production of mushrooms. However, excess organic or mineral nitrogen may inhibit the synthesis of lignin-degrading enzyme (Bisaria et al., 1997), causing a decrease in productivity, a fact also observed by Macaya-Lizano (1988) in his work with Pleurotus sp., grown on several residues and supplemented with cotton meal or soybean bran.

The mineral supplementation of washed bagasse prevented the development of contaminants on the cultivation substrate, contrary to organic supplementation, not differing, however, from the control treatment with respect to ABE. Several authors, notwithstanding, used inorganic sources in the supplementation of various substrates, increasing Pleurotus sp. productivity (Zadrazil, 1980; Bisaria et al., 1997; Permana et al., 2000). Despite its low biological efficiency, washing fresh sugarcane bagasse is a promising technique, compensating yield by means of a reduction in time and costs with infrastructure and labor. 


\section{CONCLUSIONS}

Washed fresh sugarcane bagasse is viable as a substrate for the production of the mushroom Pleurotus sajor-caju, especially in view of its low contamination and of a reduction in substrate disinfection costs;

The use of mineral solution on washed bagasse did not promote the development of contaminants, and could be perfected and used in the supplementation of this substrate.

\section{REFERENCES}

ABE, E.; EIRA, A.F.; MINHONI, M.T.A. Relações entre temperatura de pasteurização e contaminação do composto durante o cultivo de Pleurotus ostreatus (Jacquim Fries) Kummer. Científica, v.20, p.423-433, 1992.

BALASUBRAMANYA, R.H.; KATHE, A.A. An inexpensive pretreatment of cellulosic materials for growing edible oyster mushrooms. Bioresource Technology, v.57, p.303-305, 1996.

BAHUKHANDI, D.; MUNJAL, R.L. Cultivation of Pleurotus species on different agricultural residues. Indian Phytopathology, v.42, p.492495, 1989.

BANO, Z.; RAJARATHNAM, S. Pleurotus mushrooms: Part II. Chemical composition, preservation and role an human food. Critical Reviews in Food Science and Nutrition, v.27, p.87-158, 1988.

BISARIA, R.; MADAN, M.; VASUDEVAN, P. Utilization of agro-residues as animal feed through bioconversion. Bioresource Technology, v.59, p.5-8, 1997.

BONONI, V.L.; CAPELARI, M.; MAZIERO, R.; TRUFEM, S.F.B. Cultivo de cogumelos comestíveis. São Paulo: Ícone, 1995. 206p.

BUSWELL, J.A.; CHANG, S.T. Edible mushrooms: attributes and applications. In: CHANG, S.T.; BUSWELL, J.A.; MILES, P.G. Genetics and breeding of edible mushrooms. Amsterdam: Gordon and Breach Science Publishers, 1993. cap.15, p.306-318.

CHANG, S.T. Mushrooms as human food. Bioscience, v.30, p.399-401, 1980.

CHANG, S.T.; MILES, P.G. A new look at cultivated mushrooms. Bioscience, v.34, p.358-362, 1984.

CHANG, S.T.; LAU, O.W.; CHO, K.Y. The cultivation and nutritional value of Pleurotus sajor-caju. European Journal of Applied Microbiology and Biotechnology, v.12, p.58-62, 1981.

COLAUTO, N.B.; EIRA, A.F. Efeito de recipientes de contenção do substrato na distribuição da produção de $P$. sajor-caju (Fr.) Singer. Energia na Agricultura, v.10, p.19-28, 1995.

DHANDA, S.; SODHI, H.S.; PHUTELA, R.P. Nutrition and yield evaluation of oyster mushroom Pleurotus species. Indian Journal of Nutrition and Dietetics, v.33, p.275-278, 1996.

FELINTO, A.S. Cultivo de cogumelos comestíveis do gênero Pleurotus spp. em resíduos agroindustriais. Piracicaba: USP/ESALQ, 1999. 123p. (Dissertação-Mestrado).

FERREIRA, J.E.F. Produção de cogumelos. São Paulo: Ed.Agropecuária, 1998. 136p.

GABRIELLI, G.; NAGATA, C.L.; MODA, E.M.; ALCARDE, A.R.; HORII, J. Diferentes tipos de milho como semente no cultivo de Pleurotus sajorcaju (Fr.) Singer. In: ENCONTRO CIENTÍFICO DOS PÓSGRADUANDOS NO CENA-USP, 7., Piracicaba, 2002. Resumos. Piracicaba:CENA/USP, 2002.

INSTITUTO AGRONÔMICO DE CAMPINAS - IAC.. Recomendações de adubação e calagem. Campinas: IAC, 1996. 134p. (Boletim Técnico, 100).

JUSTO, M.B.; GUZMÁN, M.G.A.; MEJÍA, E.G.; DÍAZ, C.L.G. Composición química de tres cepas mexicanas de setas (Pleurotus ostreatus). Archivos Latinoamericanos de Nutricion, v.48, p.359-363, 1998.
MACAYA-LIZANO, A.V. Cultivo de Pleurotus ostreatus y especies afines (Fungi: Pleurotaceae) sobre medios naturales semi-estériles. Revista de Biologia Tropical, v.36, p.255-260, 1988.

MADAN, M.; VASUDEVAN, P.; SHARMA, S. Cultivation of Pleurotus sajor-caju on different wastes. Biological Wastes, v.22, p.241-250, 1987.

MANSUR, M.; KLIBANSKY, M.; GUTIÉRREZ, I.; GONZÁLES, L. Evaluacion de parametros de processo para la produción de hongos del gênero Pleurotus cultivados sobre paja de cana. Boletim GEPLACEA, v.9, p.11-21, 1992.

MAZIERO, R.; BONONI, V.L.; CAPELARI, M. Cultivo e produtividade de Pleurotus ostreatus var. "Flórida” em Mogi das Cruzes, S.P., Brasil. Hoehnea, v.19, p.1-7, 1992.

MIZUNO, T.; ZHUANG, C. Houbitake, Pleurotus sajor-caju - antitumoractivity and utilization. Food Reviews International, v.11, p.185-187, 1995.

ORTEGA, G.M.; MARTINEZ, E.O.; BETANCOURT, D.; GONZALÉZ, A.E.; OTERO, M.A. Bioconversion of sugar cane crop residues with white-rot fungi Pleurotus sp. World Journal of Microbiology and Biotechnology, v.8, p.402-405, 1992.

PATRABANSH, S.; MADAN, M. Studies on cultivation, biological efficiency and chemical analysis of Pleurotus sajor-caju (Fr.) Singer on different bio-wastes. Acta Biotechnologica, v.17, p.107-122, 1997.

PERMANA, I.G.; FLACHOWSKY, G.; MEULEN, U.; ZADRAZIL, F. Use of sugarcane bagasse for mushroom and animal feed production. Mushroom Science, v.15, p.385-390, 2000.

RAJARATHNAM, S.; BANO, Z. Pleurotus mushrooms: Part III. Biotransformations of natural lignocellulosic wastes commercial applications and implications. Critical Reviews in Food Science and Nutrition, v.28, p.31-113, 1989.

SAS Institute. SAS user's guide: statistics. Cary: Statistical Analysis System Institute, 2000. 584p.

STAMETS, P. Growing gourmet \& medicinal mushrooms. Berkely: Speed Press, 1993. 554p.

STURION, G.L.; OETTERER, M. Utilização da folha da bananeira como substrato para cultivo de cogumelos comestíveis (Pleurotus spp.) Ciência e Tecnologia de Alimentos, v.15, p.194-200, 1995a.

STURION, G.L.; OETTERER, M. Composição química de cogumelos comestíveis (Pleurotus spp.) originados de cultivos em diferentes substratos. Ciência e Tecnologia de Alimentos, v.15, p.189-193, 1995b.

STURION, G.L.; RANZANI, M.R.T. de C. Produção do cogumelo comestível Pleurotus: opção promissora, especialmente na região do Vale do Ribeira. Piracicaba: ESALQ, DIBD, 1997. 44p. (Série Produtor Rural, 2).

WIZENTIER, B.; MACHADO, J.O.; ANDRIOLI, J.L. Crescimento do cogumelo comestível Pleurotus sajor-caju em bagaço de cana não esterilizado. Científica, v.24, p.341-352, 1996.

YARA, R. Bactéria associada a Pleurotus sp. São Paulo: USP/IB, 2002. 134p. (Dissertação - Mestrado).

ZADRAZIL, F. Influence of ammonium nitrate and organic supplements on the yield of Pleurotus sajor-caju (Fr.) Singer. European Journal of Applied Microbiology and Biotechnology, v.9, p.31-35, 1980.

ZANETTI, A.L.; RANAL, M.A. Efeitos de diferentes resíduos agroindustriais na miceliação de Pleurotus sp. "Florida”, em Uberlândia, M.G. Pesquisa Agropecuária Brasileira, v.31, p.215-220, 1996.

ZANETTI, A.L.; RANAL, M.A. Suplementação da cana-de-açúcar com guandu no cultivo de Pleurotus sp. "Florida”. Pesquisa Agropecuária Brasileira, v.32, p.959-964, 1997.

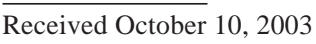

Accepted February 01, 2005 